\title{
Food lodine Content Table compiled from international databases
}

\section{Tabela do Conteúdo de Iodo de Alimentos compilada de bancos de dados internacionais}

\author{
Regina Célia Rodrigues de Miranda MILAGRES 1 (D) 0000-0002-0523-8566 \\ Eliana Carla Gomes de SOUZA 1 (iD) 0000-0002-2229-7429 \\ Maria do Carmo Gouveia PELUZIO² (D) 0000-0003-4665-7043 \\ Sylvia do Carmo Castro FRANCESCHIN| ${ }^{3}$ (D) 0000-0001-7934-4858 \\ Maria Sônia Lopes DUARTE4 ${ }^{4}$ 0000-0002-0887-5739
}

A B S T R A C T

In Brazil, there are no data on the iodine content of foods, making it difficult for the population to assess their consumption of iodine. Such information is necessary for public policies aimed at establishing nutritional goals. The objective this article is to construct a table of the iodine content of foods. For the construction of the table, databases from 14 countries were used. The foods used were those listed in the 2008-2009 Household Budget Survey, except those containing added salt, and the doubts about whether or not the food was submitted to any kind of preparation. The compilation of international databases of iodine content resulted in 266 foods, which were grouped into 15 groups. Iodine was also quantified by food group and iodized salt. Data were presented as median, minimum, and maximum. A broad variation in the iodine content of foods was found

1 Universidade Federal de Viçosa, Centro de Ciências Biológicas e da Saúde, Laboratório de Análise de Alimentos. Av. Peter Henry Rolfs, s/n., Campus Universitário, 36570-900, Viçosa, MG, Brasil. Correspondence to: RCRM MILAGRES. E-mail: <reginamilagres@ufv.br>.

2 Universidade Federal de Viçosa, Centro de Ciências Biológicas e da Saúde, Laboratório de Estudo Experimental de Alimentos. Viçosa, MG, Brasil.

${ }^{3}$ Universidade Federal de Viçosa, Centro de Ciências Biológicas e da Saúde, Programa de Pós-Graduação em Ciência da Nutrição. Viçosa, MG, Brasil.

${ }^{4}$ Universidade Federal de Viçosa, Centro de Ciências Biológicas e da Saúde, Departamento de Nutrição e Saúde. Viçosa, MG, Brasil.

Support: Conselho Nacional de Desenvolvimento Científico e Tecnológico (CNPq, Brazilian National Council for Scientific and Technological Development) and Ministério da Saúde (Healthy of Ministery) (Process n. 408295/2017-1) and Fundação de Amparo e Pesquisa do Estado de Minas Gerais (FAPEMIG, Research Support Foundation of the States of Minas Gerais) (Process n. APQ-03336-18).

\section{How to cite this article}

Milagres RCRM, Souza ECG, Peluzio MCG, Franceschini SC, Duarte MSL. Food Iodine Content Table compiled from international databases. Rev Nutr. 2020;33:e190222. https://doi.org/10.1590/1678-9865202033e190222 
between countries and inter- and intra-food groups. Those with the highest content were fish and seafood, and dairy products. Regarding salt iodization, these countries followed the recommendation of the World Health Organization, except for Spain, Norway and Turkey. The Food lodine Content Table can be a useful tool for assessing iodine intake, being important in research on nutritional status, food guidance, and public health programs.

Keywords: Food composition. Food consumption. Mineral.

\section{RE S U M O}

O objetivo deste trabalho é construir uma tabela de conteúdo de iodo de alimentos visto que tais informações são necessárias para que políticas públicas possam estabelecer metas nutricionais e no Brasil não existem dados do conteúdo de iodo dos alimentos, dificultando a avaliação do consumo pela população. Na construção da tabela utilizou-se bancos de dados de 14 países. Os alimentos utilizados foram aqueles listados na Pesquisa de Orçamentos Familiares de 2008-2009, exceto aqueles que continham sal de adição e os que suscitaram dúvidas em relação à existência de submissão ou não a algum preparo. A compilação dos bancos de dados internacionais do conteúdo de iodo resultou em 266 alimentos, os quais foram reunidos em 15 grupos. Foi realizada também a quantificação de iodo por grupo de alimentos e no sal iodado. Os dados foram apresentados como mediana, mínimo e máximo. Foi encontrada grande variação no conteúdo de iodo dos alimentos entre os países e inter e intra grupos de alimentos. Os que apresentaram maiores conteúdos foram o dos pescados e frutos do mar e dos laticínios. Em relação à iodação do sal, os países seguiram a recomendação da Organização Mundial da Saúde, exceto, Espanha, Noruega e Turquia. A tabela do conteúdo de iodo de alimentos poderá ser um instrumento útil para avaliação da ingestão de iodo, sendo importante em pesquisa do estado nutricional, orientação alimentar e programas de saúde pública.

Palavras-chave: Composição de alimentos. Consumo alimentar. Mineral.

\section{NTRODUCTION}

lodine is essential in the synthesis of thyroid hormones, necessary for growth, development, and metabolism in the human body. Its inadequate intake can lead to thyroid dysfunction, causing a series of adverse health conditions, such as hypertrophy of the thyroid gland (goiter), cretinism in children (severe and irreversible mental retardation), deafness and congenital anomalies, cognitive changes (such as decreased learning capacity), and infant mortality [1-3]. lodine deficiency is considered the main cause of preventable mental retardation [4-6]. On the other hand, it is observed that excessive iodine consumption can increase the risk of induced hyperthyroidism [7].

About $20 \%$ of the world population is at risk of iodine deficiency, being more prevalent in developing countries, although its mild or moderate form is found in industrialized countries [8]. Still, iodine deficiency is found in one third of the world population, in the groups of pregnant women, children, and healthy non-pregnant adults [9].

There was a reduction in the prevalence of iodine deficiency in the world, with the following chronological order: in 2003, fifty-four countries were considered iodine deficient, in 2011, they were reduced to thirty-two [10]. This reduction was due to the salt iodization programs and better monitoring of iodine deficiency [11]. In Brazil, due to the high consumption of added salt, and processed and ultra-processed foods, salt iodination was changed from 20 to $60 \mathrm{ppm}$ to 15 to $45 \mathrm{ppm}$ [2].

Differences in the iodine content of foods, together with different eating habits, are decisive factors in the iodine nutritional status in the population [12]. The distribution of iodine in the world is uneven, since the geographical characteristics interfere with its content in food $[2,13]$. Glaciation, flooding, and erosion remove iodine from the soil and thus it is mainly found in seas and oceans, 
which justifies the higher content in foods of marine origin (algae, fish, and shellfish). Geochemical data demonstrate that iodine deficiency in food is related to the low concentration of iodine in the environment, especially in groundwater, which is the main source of water for the population [14].

In Brazil, there is no data on the iodine content of national foods, making it difficult to assess iodine consumption by the population. This information is necessary so that public policies can establish nutritional goals. In this sense, the construction of the Food lodine Content Table (FICT) becomes an important pillar in the provision of subsidies for the assessment of iodine intake.

\section{METHODS}

The construction of the Food lodine Content Table (FICT) is part of the Projeto Multicêntrico de Deficiência de lodo: Brazil (EMDI, Multicentric lodine Deficiency Project). The EMDI project aims to assess the magnitude of the deficiency and the factors associated with the iodine nutritional status in Brazilian pregnant women, nursing mothers, and infants.

For the construction of the Food lodine Content Table (FICT), the review article entitled "Development of databases on iodine in foods in dietary supplements" was used [15]. It contains a list of all countries that had a database of iodine content in food. Of the 24 countries, only 14 made their databases available for consultation. Chart 1 shows the 14 countries consulted and their documents or databases.

Chart 1. Countries and documents or databases consulted for the construction of the Food lodine Content Table.

\begin{tabular}{ll}
\hline Countries & \multicolumn{1}{c}{ Documents or Databases } \\
\hline Australia & Australian Food, Supplement and Nutrient Database 2011-13 [16] \\
Bahrain & Food Composition Tables for Kindgom of Bahraim [17] \\
Denmark & Frida Database [18] \\
Spain & Base de Datos Española de Composión de Alimentos [19] \\
France & Ciqual French food composition table [20] \\
Netherlands & Nederlands Voedingsstoffenbestand (NEVO) [21] \\
Italy & Banca Dati di Composizione degli Alimenti per Studi Epidemiologici in Italia [22] \\
Japan & Standards Tables of Food Composition in Japan [23] \\
Norway & Norwegian Food Composition Database [24] \\
New Zealand & New Zealand Food Composition Database [25] \\
United Kingdom & Composition of foods integrated dataset [26] \\
Sweden & The Swedish Food Composition Database [27] \\
Switzerland & The Swiss Food Composition Database [28] \\
Turkey & Turkish Food composition Database [29] \\
\hline
\end{tabular}

Source: Adapted from Ershow et al. [15].

The foods used to construct the FICT were those listed in the 2008-2009 Pesquisa de Orçamentos Familiares (POF, Household Budget Survey): Table of the Nutritional Composition of Foods Consumed in Brazil [30]. The option was made to search for foods that did not contain added salt since, in different countries, the levels of iodine added to salt vary. In addition, foods that raised doubts regarding the existence of preparation or not (e.g. cappuccino, instant coffee) were excluded. The diagram below illustrates the stages of construction of the FICT (Figure 1).

To build the FICT, international iodine content databases were compiled, resulting in 266 foods, which were grouped into 15 food groups as described in the POF: Cereals and legumes; Tuberous vegetables; Flours, starches, and pasta; Coconuts, chestnuts, and walnuts; Leafy vegetables, fruits, and others; Fruits; Sugars and pastries; Condiments; Meat and offal; Fish and seafood; Poultry and 
eggs; Dairy products; Non-alcoholic drinks and infusions; Oils and fats; and Miscellaneous [30]. The iodine contents in salt were compiled separately due to the divergence of iodine levels in different countries, as they adopt specific legislation for salt enrichment.

The data were described as median (minimum and maximum), expressed in $\mu \mathrm{g}$ of iodine per $100 \mathrm{~g}$ of food in the FICT. For foods whose data were obtained from only one country, the figures were presented only in absolute terms.

Foods contained in the Household Budget Survey (2008-2009)

\section{1,971 foods}

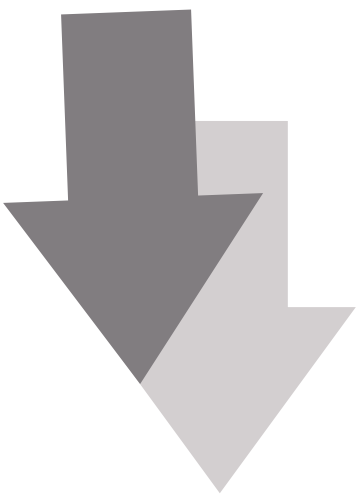

1,131 foods

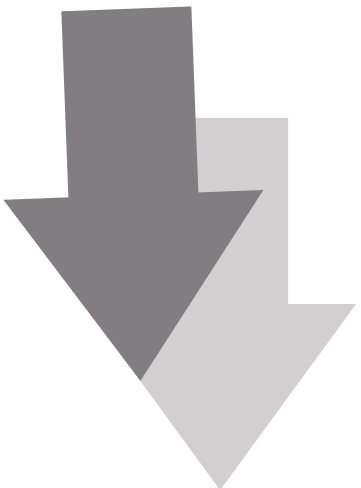

422 foods

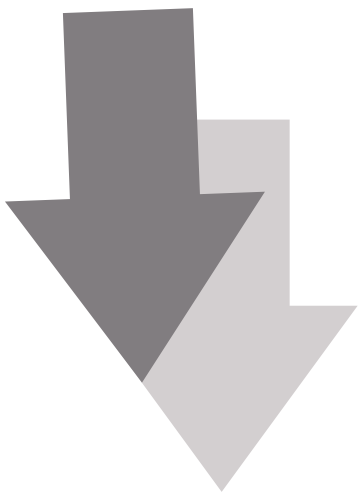

266 foods
Exclusion of prepared foods and/or processed/ultra-processed foods with added salt

Exclusion of foods not found in the databases undetected iodine content

Figure 1. Flowchart of food selection. 


\section{RES U L T S}

The Table 1 shows the Food lodine Content Table compiled from international databases and the specification of countries that provided data on iodine content. The number of foods and the median (minimum and maximum) iodine content per food group are shown in Table 2. The fish and seafood group had the highest iodine levels. In addition to this, the groups of dairy products and tuberous vegetables stood out in relation to the highest iodine contents among food groups. Regarding the iodine content in iodized salt, a large variation was found, up to 10 times more, in different countries (Table 3).

Table 1. Table of Food lodine Content compiled from international databases.

1 of 5

\begin{tabular}{|c|c|c|c|}
\hline Food & Country $^{*}$ & Median $\mu \mathrm{g} 100 \mathrm{~g}^{-1}$ & Min-Max $\mu \mathrm{g} 100 \mathrm{~g}^{-1}$ \\
\hline \multicolumn{4}{|l|}{ Cereals and legumes } \\
\hline Rice (polished, parboiled, agulha, agulhinha, etc.) & $1,3,4,6,8,9,10,11,13$ & 2.00 & $0.00-2.60$ \\
\hline Brown rice & $1,6,8,11$ & 2.00 & $0.00-5.00$ \\
\hline Corn (grain) & $4,5,6,8,10,12,13$ & 0.50 & $0.00-5.00$ \\
\hline Peanut (grain) - in natura & $1,4,6,7,8,9,10,11,12,13$ & 2.10 & $0.50-20.00$ \\
\hline Pea beans & $1,3,4,8,11,13$ & 1.30 & $0.15-2.00$ \\
\hline Broad beans (grain) & 4,8 & 1.00 & $0.00-2.00$ \\
\hline Green beans & $1,3,4,11,12,13$ & 1.00 & $0.80-3.00$ \\
\hline Linseed & $1,12,13$ & 5.00 & $0.00-10.00$ \\
\hline Chickpeas & $4,5,8,9,12,13$ & 1.15 & $0.60-2.80$ \\
\hline Lentil & $1,3,4,5,9,10,12,13$ & 0.70 & $0.40-5.70$ \\
\hline Soybeans & $3,4,5,8,11,12,13$ & 2.00 & $0.00-24.00$ \\
\hline Beans (black, mulatinho, purple, rosinha, etc.) & $1,2,3,4,5,8,9,10,11,12,13$ & 1.90 & $0.00-6.70$ \\
\hline Organic green beans & 13 & $25.00^{* *}$ & - \\
\hline Light popcorn & 5,13 & 1.25 & $0.00-2.50$ \\
\hline Quinoa & $1,9,10$ & 0.50 & $0.20-0.60$ \\
\hline \multicolumn{4}{|l|}{ Tuberous Vegetables } \\
\hline Potato & $1,3,4,6,9,11,12,13$ & 1.20 & $0.20-2.60$ \\
\hline Sweet potato & $1,4,6,8,11,13$ & 1.60 & $0.00-2.00$ \\
\hline Yam & $8,10,13$ & 1.00 & $0.00-1.60$ \\
\hline Cassava / manioc & $1,9,13$ & 1.80 & $1.60-2.00$ \\
\hline Amerindian yam & 13 & $1.60^{* *}$ & - \\
\hline Radish & $1,3,4,6,8,9,12,13$ & 1.00 & $0.70-3.00$ \\
\hline Beet & $1,3,5,9,10,12$ & 0.50 & $0.30-0.90$ \\
\hline Carrot & $1,2,3,4,6,9,12,13$ & 1.80 & $0.40-9.50$ \\
\hline Turnip & 1,4 & 10.25 & $0.50-20.00$ \\
\hline Saffron & 9 & $11.00^{* *}$ & - \\
\hline Organic potato & 6 & $2.00^{* *}$ & - \\
\hline \multicolumn{4}{|l|}{ Flours, Starches, and Pasta } \\
\hline Oatmeal flour & $4,6,8,9,10,13$ & 0.50 & $0.00-20.00$ \\
\hline Rolled oats & $4,9,10,13$ & 1.25 & $0.00-6.00$ \\
\hline Corn flour & $1,3,4,5,6,9$ & 0.60 & $0.60-1.00$ \\
\hline Maize starch & $1,3,4,5,6,8,9,12,13$ & 0.70 & $0.00-3.70$ \\
\hline Rice starch & 4 & $0.60^{* *}$ & - \\
\hline Flaked corn breakfast cereal & $3,4,5,6,9,10,12$ & 0.90 & $0.00-5.00$ \\
\hline Wheat germ & $1,3,4,5,12,13$ & 0.25 & $0.15-5.00$ \\
\hline Wheat fiber & 4,13 & 1.55 & $0-30.1 .00$ \\
\hline Cereal flakes & $9,12,13$ & 1.50 & $0.00-2.00$ \\
\hline Spaghetti & $3,4,5,9,11,13$ & 1.95 & $0.60-12.00$ \\
\hline Ground peanuts & $1,8,13$ & 2.10 & $1.00-3.20$ \\
\hline Granola & 4 & $5.00^{* *}$ & - \\
\hline Muslix & 3 & $0.91^{* *}$ & - \\
\hline Cereal mix & 4 & $8.50^{* *}$ & - \\
\hline Instant noodles & 4 & $6.90^{* *}$ & - \\
\hline Soy protein & 1 & $1.00^{* *}$ & - \\
\hline Organic soy protein & 1 & $1.00^{* *}$ & - \\
\hline
\end{tabular}


Table 1. Table of Food lodine Content compiled from international databases.

2 of 5

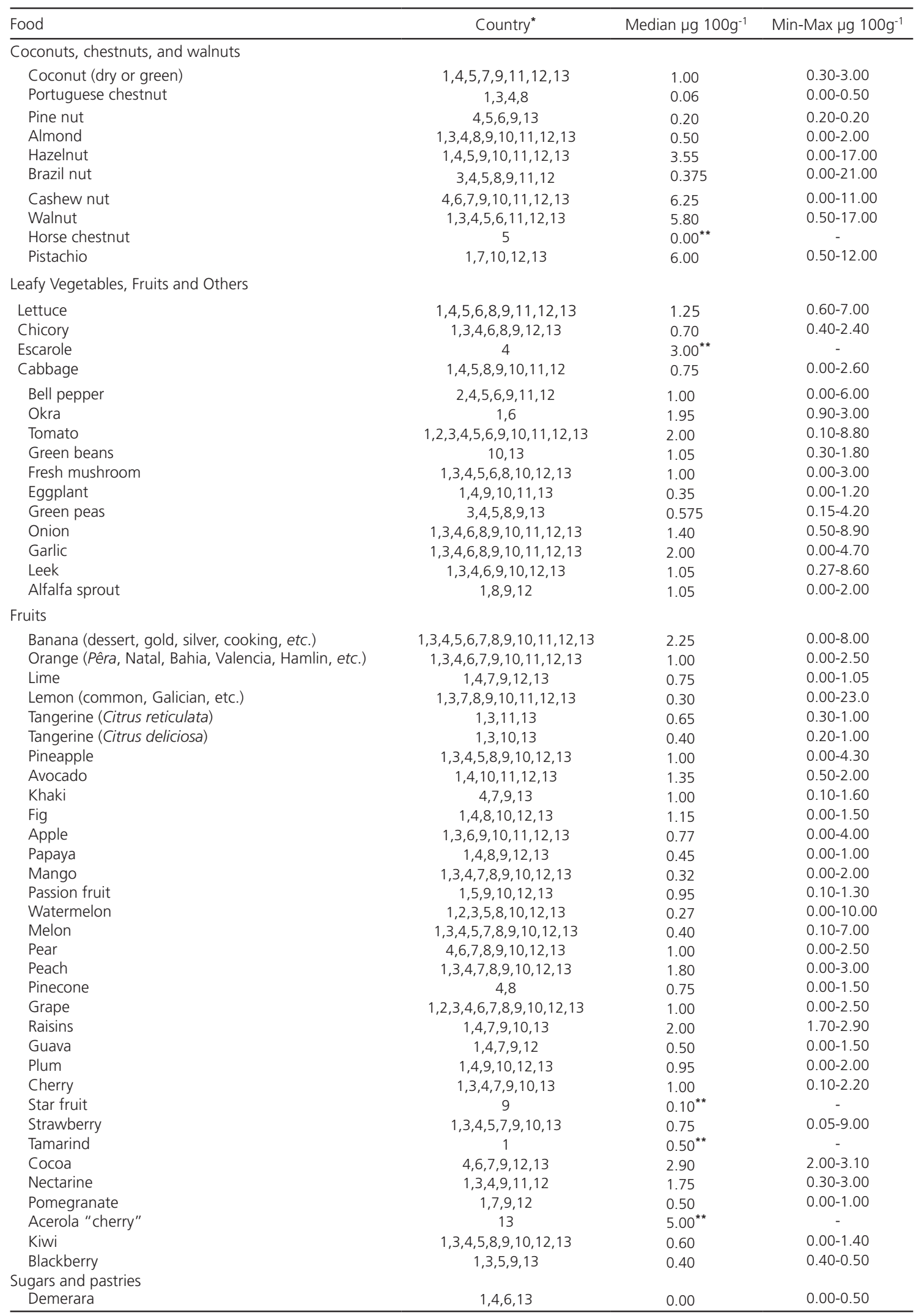


Table 1. Table of Food lodine Content compiled from international databases.

3 of 5

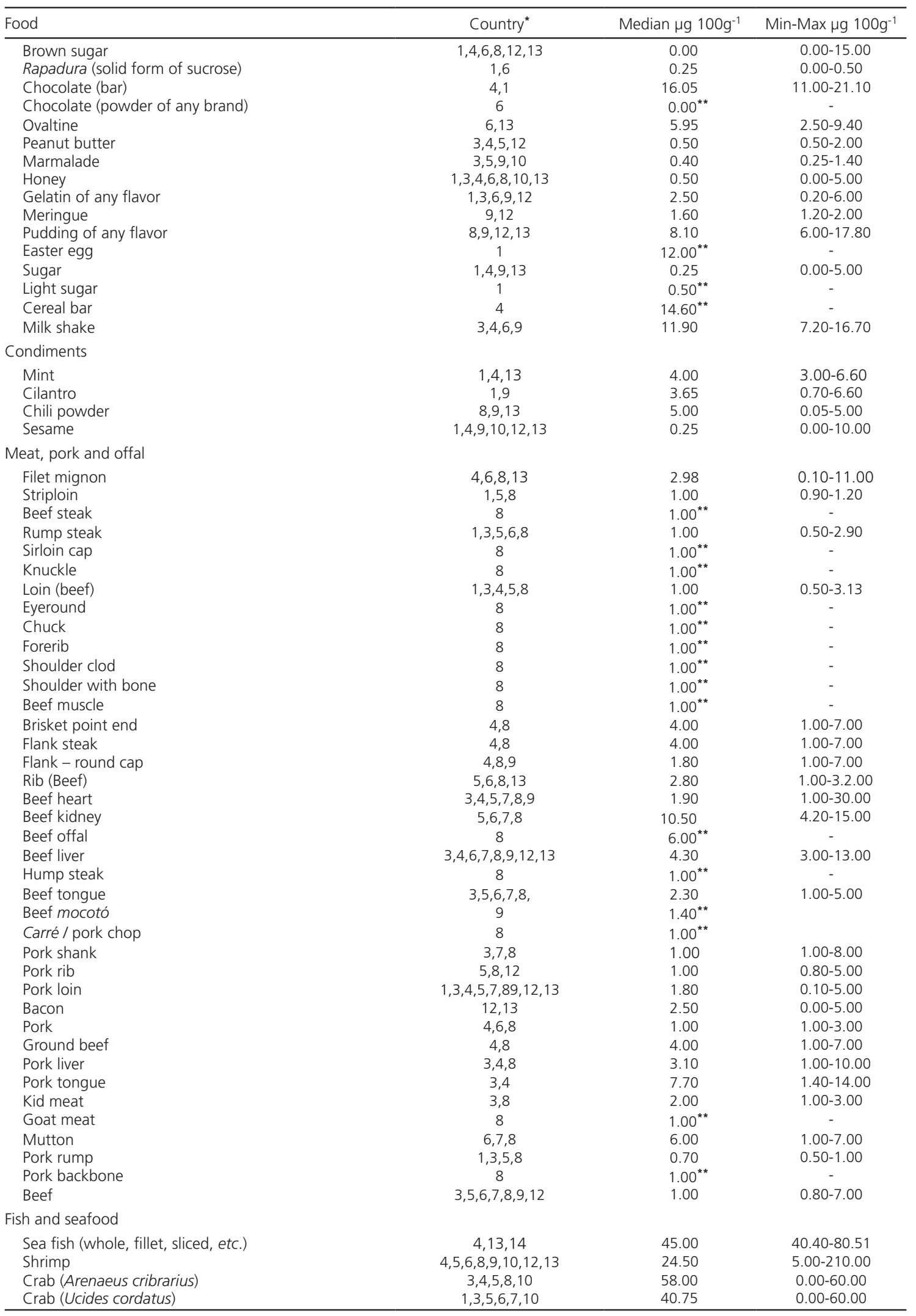


Table 1. Table of Food lodine Content compiled from international databases.

4 of 5

\begin{tabular}{|c|c|c|c|}
\hline Food & Country* & Median $\mu \mathrm{g} 100 \mathrm{~g}^{-1}$ & Min-Max $\mu \mathrm{g} 100 \mathrm{~g}^{-1}$ \\
\hline Shellfish & $8,13,14$ & 101.13 & $73.00-130.00$ \\
\hline Oyster & $1,3,4,5,6,7,8,9,10,12$ & 66.50 & $20.00-160.00$ \\
\hline Squid & $1,4,5,7,8,13$ & 20.00 & $8.00-64.00$ \\
\hline Fish eggs (any species) & 1 & $27.00^{* *}$ & - \\
\hline Unspecified fish (whole, fillet, sliced, etc.) & 1 & $35.50^{* *}$ & - \\
\hline \multicolumn{4}{|l|}{ Poultry and eggs } \\
\hline Whole chicken & $1,3,4,5,6,7,8$ & 4.10 & $0.40-8.00$ \\
\hline Chicken breast & $1,4,5,6,7,8,9,10$ & 1.40 & $0.50-8.00$ \\
\hline Chicken fillet & $1,4,6,8,9$ & 1.80 & $1.00-5.00$ \\
\hline Chicken wings & $1,4,6,8$ & 5.00 & $1.00-6.90$ \\
\hline Chicken gizzards & 5,8 & 0.70 & $0.40-1.00$ \\
\hline Chicken heart & $1,4,8,9,12$ & 1.20 & $0.00-7.00$ \\
\hline Chicken liver & $1,4,6,9,10,12$ & 2.70 & $1.40-5.00$ \\
\hline Turkey (unspecified parts) & $4,7,12$ & 2.20 & $2.00-5.00$ \\
\hline Turkey wing & 4,7 & 4.00 & $2.00-6.00$ \\
\hline Quail & 1 & $3.10^{* *}$ & - \\
\hline Chicken wings and feet & 6,7 & 6.50 & $5.00-8.00$ \\
\hline Chicken eggs & $1,2,3,4,5,6,7,8,9,12,13$ & 32.00 & $2.00-57.60$ \\
\hline Quail egg & 1,4 & 50.80 & $44.00-57.60$ \\
\hline Duck breast & 6,8 & 4.10 & $1.2-7.00$ \\
\hline Duck meat & $1,4,6,7,8$ & 1.20 & $1.2-7.00$ \\
\hline \multicolumn{4}{|l|}{ Dairy products } \\
\hline Whole cow milk & $1,3,4,5,6,8,9,13$ & 14.85 & $9.00-24.80$ \\
\hline Fresh cow milk & $1,2,3,4,5,8,9,10$ & 17.90 & $7.00-52.50$ \\
\hline Goat milk & $1,4,13$ & 10.00 & $5.00-22.30$ \\
\hline Powdered milk & $1,2,3,4,5,6,7,10,12$ & 30.00 & $7.00-150.00$ \\
\hline Condensed milk & $4,5,6,7,8,12,13$ & 35.00 & $8.00-160.00$ \\
\hline Table cream & 8,12 & 9.20 & $8.00-10.40$ \\
\hline Whipped cream & 6,12 & 8.60 & $7.30-9.90$ \\
\hline Yogurt of any flavor & $3,4,5,6,7,8,9,11,12,13$ & 11.70 & $5.50-48.00$ \\
\hline Low-fat yogurt & $1,3,4,5,6,7,8,11,12,13$ & 14.45 & $5.30-48.00$ \\
\hline Natural yogurt & $1,3,5,6,7,8,9,11,12,13$ & 13.50 & $8.00-63.00$ \\
\hline Dairy beverages & $4,5,11$ & 24.30 & $11.00-25.00$ \\
\hline Fermented milk & $3,4,5,6,12$ & 6.00 & $4.00-24.30$ \\
\hline Curd & 4,12 & 12.00 & $9.00-15.00$ \\
\hline Flavored soy milk & $1,3,4,6,11,12,13$ & 1.00 & $0.00-90.35$ \\
\hline Unspecified cheese & $4,5,13$ & 4.80 & $1.70-24.20$ \\
\hline Flavored milk & 1 & $6.00^{* *}$ & - \\
\hline Aromatized milk & 1 & $6.00^{* *}$ & - \\
\hline Cream & $1,4,10,12,13$ & 8.00 & $1.00-12.00$ \\
\hline Skimmed cow milk & $4,5,6,9,12,13$ & 14.15 & $3.10-16.00$ \\
\hline Semi-skimmed cow milk & $3,4,5,9,10,13$ & 11.15 & $8.50-20.00$ \\
\hline Pasteurized, unspecified milk type & $3,5,9$ & 11.70 & $7.00-14.80$ \\
\hline Flavored milk & $8,9,10$ & 13.00 & $6.30-14.00$ \\
\hline Aromatized milk & 8,9 & 14.50 & $13.00-16.00$ \\
\hline \multicolumn{4}{|l|}{ Non-Alcoholic Drinks and Infusions } \\
\hline Traditional cola soda & $2,4,5,7,13$ & 0.00 & $0.00-4.10$ \\
\hline Traditional Coca Cola & 4,7 & 0.50 & $0.00-1.00$ \\
\hline Traditional orange soda & 5 & $0.40^{* *}$ & - \\
\hline Traditional guarana soda & 5 & $0.40^{* *}$ & - \\
\hline Diet yogurt of any flavor & 5 & $0.40^{* *}$ & - \\
\hline Traditional grape soda & 4,5 & 0.20 & $0.00-0.40$ \\
\hline Coconut water & 1,12 & 0.25 & $0.00-0.50$ \\
\hline Yeast & 13 & $4,00^{* *}$ & - \\
\hline Barley powder & $3,4,6,9,13$ & 0.50 & $0.20-5.00$ \\
\hline Traditional tonic water & 1,13 & 0.30 & $0.00-0.60$ \\
\hline Diet tea (black, chamomile, lemon balm, lemon grass, etc.) & $2,3,6,13$ & 0.70 & $0.22-2.80$ \\
\hline Energy drink & 1,9 & 0.25 & $0.00-0.50$ \\
\hline Tea (black, chamomile, lemon balm, lemon grass, etc.) & $5,6,9,13$ & 0.31 & $0.00-1.00$ \\
\hline Nescafé & 1 & $0.60^{* *}$ & - \\
\hline Yeast & 1 & $16.60^{* *}$ & - \\
\hline Beer (with alcohol) & $1,3,4,5,7,8,9,12,13$ & 1.00 & $0.00-8.00$ \\
\hline Brandy / cachaça & 1 & $0.50^{* *}$ & - \\
\hline Vodka & $1,4,12$ & 0.00 & $0.00-0.50$ \\
\hline
\end{tabular}


Table 1. Table of Food lodine Content compiled from international databases.

5 of 5

\begin{tabular}{|c|c|c|c|}
\hline Food & Country $^{*}$ & Median $\mu \mathrm{g} 100 \mathrm{~g}^{-1}$ & Min-Max $\mu \mathrm{g} 100 \mathrm{~g}^{-1}$ \\
\hline Whiskey & 1 & $0.50^{* *}$ & - \\
\hline Champagne & 3 & $35.00^{* *}$ & - \\
\hline Champagne cider & $1,5,6,13$ & 1.10 & $0.50-10.00$ \\
\hline Cognac & 1,13 & 0.25 & $0.00-0.50$ \\
\hline Wine & $1,3,4,5,6,7,9,10,13,14$ & 2.00 & $0.00-10.00$ \\
\hline Beer (without alcohol) & $1,7,9$ & 0.75 & $0.50-1.00$ \\
\hline \multicolumn{4}{|l|}{ Oil and fat } \\
\hline Olive oil & $3,4,5,8,12,13$ & 0.00 & $0.00-0.00$ \\
\hline Soy oil & $1,3,5,8,9,12,13$ & 0.00 & $0.00-0.80$ \\
\hline Pork lard & $1,3,5,7,8$ & 1.80 & $0.00-7.00$ \\
\hline Lard & 1 & $0.50^{* *}$ & - \\
\hline Palm oil & 12 & $0.00^{* *}$ & - \\
\hline \multicolumn{4}{|l|}{ Miscellaneous } \\
\hline Pineapple juice & $1,5,9,10$ & 1.05 & $0.20-1.90$ \\
\hline Orange juice & $1,3,4,5,6,7,8,9,10,12,13$ & 1.00 & $0.00-2.00$ \\
\hline Mango juice & 4,5 & 1.90 & $0.80-3.00$ \\
\hline Peach juice & 7,1 & 1.80 & $0.60-3.00$ \\
\hline Peach juice syrup & 13 & $2.60^{* *}$ & - \\
\hline Banana smoothie & 1 & $11.20^{* *}$ & - \\
\hline Smoothie & 1 & $11.30^{* *}$ & - \\
\hline Gooseberry & 4 & $1.00^{* *}$ & - \\
\hline Lemon soda & 7 & $1.00^{* *}$ & - \\
\hline Coffee with milk & $4,5,8,9,11,13$ & 3.85 & $2.00-17.40$ \\
\hline Espresso & $1,5,9,10,12$ & 1.10 & $0.10-3.00$ \\
\hline
\end{tabular}

Note: ${ }^{*}$ The references to access the international iodine content tables can be seen in Chart $1{ }^{* *}$ The absolute values were presented because these foods were found in the database of only one country; 1: Australia; 2: Bahrain; 3: Denmark; 4: Spain; 5: France; 6: Netherlands; 7: Italy; 8: Japan; 9: Norway; 10: New Zealand; 11: United Kingdom; 12: Sweden; 13: Switzerland; 14: Turkey.

Table 2. Number of foods and median (minimum and maximum) iodine content of foods in the groups.

\begin{tabular}{lccc}
\hline Food groups & Number of foods & ${ }^{*}$ Median $\mu \mathrm{g} 100 \mathrm{~g}^{-1}$ & Min-max $\mu \mathrm{g} 100 \mathrm{~g}^{-1}$ \\
\hline Cereals and Legumes & 15 & 1.30 & $0.50-25.00$ \\
Tuberous Vegetables & 11 & 1.80 & $0.50-10.25$ \\
Flours, Starches, and Pasta & 17 & 1.00 & $0.50-8.50$ \\
Coconuts, Chestnuts, and Walnuts & 10 & 0.55 & $0.10-6.25$ \\
Leafy Vegetables, Fruits and Others & 33 & 1.05 & $0.15-5.00$ \\
Fruits & 33 & 0.77 & $1.00-5.00$ \\
Sugars and Pastries & 17 & 0.50 & $0.00-16.05$ \\
Salts and Condiments & 4 & 3.82 & $0.25-5.00$ \\
Meat and offal & 39 & 1.00 & $0.70-10.50$ \\
Fish and Seafood & 9 & 40.75 & $20.00-101.13$ \\
Poultry and Eggs & 15 & 3.1 & $0.70-50.80$ \\
Dairy products & 23 & 11.70 & $1.00-17.90$ \\
Non-Alcoholic Drinks and Infusions & 24 & 0.50 & $0.00-35.00$ \\
Oil and fat & 5 & 0.00 & $0.00-1.80$ \\
Miscellaneous & 11 & 1.80 & $1.00-11.30$ \\
\hline
\end{tabular}

Note: "The references to access the international iodine content tables can be seen in Chart 1.

\section{DISCUSSION}

A great variation was found in the iodine content of foods among countries, as shown in the Food lodine Content Table (FICT) compiled from the international databases (Table 1). These findings can be justified by the interference of geographical characteristics in the iodine content, since it is proportional to its content in each country's soil and water [13]. This variability is also related to animal and plant production practices and the type of food processing [15]. It is worth mentioning that, in this study, prepared and processed/ultra-processed foods with added salt were not listed. 
Table 3. lodine content in iodized salt from different countries.

\begin{tabular}{lc}
\hline Countries & ${ }^{*}$ lodized salt $\mu \mathrm{g} 100 \mathrm{~g}^{-1}$ \\
\hline Australia & 4400.00 \\
Bahrain & - \\
Denmark & 1560.00 \\
Spain & 600.00 \\
France & 1860.00 \\
Netherlands & - \\
Italy & - \\
Japan & $* *$ \\
Norway & 500.00 \\
New Zealand & 4900.00 \\
United Kingdom & - \\
Sweden & 5000.00 \\
Switzerland & 2500.00 \\
Turkey & 950.81 \\
\hline
\end{tabular}

Note: ${ }^{*}$ The references to access the international iodine content tables can be seen in Chart $1 .{ }^{* *}$ Value not found.

The high iodine content found in the fish and seafood group may be related to the fact that iodine is naturally found in seas and oceans, accumulating in marine organisms [14,31]. Meanwhile, the expressive iodine content of the dairy group can be explained by the fact that iodine is used to fortify food for cows, or as an antiseptic for udders and containers [4]. If the animals are fed with plants that grew in soil with low in iodine, the content of this element may be poor as well [1]. This fact may justify the great variability in iodine content within this group. Another group where iodine contents also stood out was the tuberous vegetables group, probably because iodine is deposited in the terrestrial environment by rain, from the evaporation of marine water [31].

Regarding iodized salt, the large variation in iodine content is possibly related to differences in the amount of iodine added in the process of salt enrichment $[15,32]$, since the WHO suggests that the average amount of iodine added to the salt should be based on the estimated consumption of salt by the population, with 14 to $65 \mathrm{mg} \mathrm{kg}^{-1}$ of iodine in the salt (1400 to $6500 \mu \mathrm{g} 100 \mathrm{~g}^{-1}$ ), for an estimated salt intake from $14 \mathrm{~g} /$ day to $3 \mathrm{~g} /$ day, respectively [8]. As observed in the databases, Spain, Norway, and Turkey did not comply with this recommendation. In Brazil, the reduction of the salt iodization levels from 2000-6000 $\mu \mathrm{g} 100 \mathrm{~g}^{-1}$ to $1500-4500 \mu \mathrm{g}$

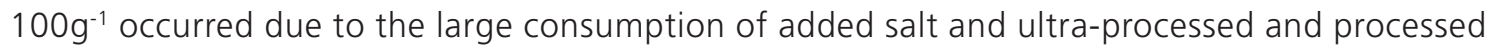
foods [2].

The main limitation of the FICT, for its use in Brazil, is the fact that its data are compiled from other countries, not from food produced in Brazil. However, because it is intercontinental data, this discrepancy may have been minimized. Considering the scarcity of these data in Brazil and the importance of iodine analysis in dietary assessment, the FICT becomes an indispensable instrument for assessing iodine consumption.

\section{CONCLUSION}

Information on the iodine content in foods is essential for assessing their intake, being important in research of nutritional status, dietary guidance, and public health programs. Therefore, the FICT, compiled from international databases, becomes an essential tool for this purpose, since there are no data produced in Brazil on the iodine content in foods. 


\section{CONTRIBUTORS}

RCRM MILAGRES, participated in the design, analysis, and interpretation of data, review and approval of the final version of the article. ECG SOUZA and MSL DUARTE participated in the conception, design, analysis, and interpretation of data, review and approval of the final version. MCG PELUZIO and SC FRANCESCHINI participated in the conception, design, analysis, and interpretation of data.

\section{RE F E R E NCES}

1. Miller JC, MacDonell SO, Gray AR, Reid MR, Barr DJ, Thomson CD, et al. lodine status of New Zealand elderly residents in long-term residential care. Nutrients. 2016;445(8):1-17. https://doi.org/10.3390/nu8080445

2. Agência Nacional de Vigilância Sanitária (Brasil). Resultado do monitoramento do teor de iodo no sal para consumo humano: relatório ano 2014. Brasília: Agência; 2014.

3. Rohner F, Zimmermann M, Jooste P, Pandav C, Caldwell K, Raghavan R, et al. Biomarkers of nutrition for development-iodine review. J Nutr. 2014;144(8):1322S-42S. https://doi.org/10.3945/jn.113.181974

4. Ascaso MTG, Perez PR, Alcol EA, Lopez AL, Lucas Collantes C, Santos IM, et al. Nutritional status of iodine in children: when appropriateness relies on milk consumption and not adequate coverage of iodized salt in households. Clin Nutr Espen. 2019;30:52-8. https://doi.org/10.1016/j.clnesp.2019.02.007

5. Gärtner R. Recent data on iodine intake in Germany and Europe. J Trace Elem Med Biol. 2016;37:85-9. https://doi.org/10.1016/j.jtemb.2016.06.012

6. Vasydevan S, Senthilvel S, Sureshbabu J. Knowledge attitude and practice on iodine deficiency disorder and iodine level in salt in retail and vendors among the rural population in south India: A community based observational and descriptive study. Clin Epidem Global Helt. 2019;7(3):300-5. https://doi.org/10.1016/j. cegh.2018.10.002

7. Vargas-Uricoechea H, Pinzón-Fernández MV, Bastidas-Sánchez BE. Historia del bocio endémico, desde ShengNung hasta los programas de yodación universal de la sal en Latinoamérica. CES Med. 2018;32(2):167-177. http://doi.org/10.21615/cesmedicina.32.2.10

8. World Health Organization. Fortification of food-grade salt with iodine for the prevention and control of iodine deficiency disorders: guideline. Geneva: Organization; 2014 [cited 2019 Jul 10]. Available from: http:// www.who.int/nutrition/publications/guidelines/fortification_foodgrade_saltwithiodine/en/

9. Anaforoğlu I, Algün E, İnceçayir Ö, Topbaş M, Erdoğan MF. lodine status among pregnant women after mandatory salt iodisation. Br J Nutr. 2016;115(3):405-10. https://doi.org/10.1017/S0007114515004559

10. Delshad H, Touhidi M, Abdollahi Z, Hedayati M, Salehi F, Azizi F. Inadequate iodine nutrition of pregnant women in an area of iodine sufficiency. J Endocrinol Invest. 2016;39(7):755-62. https://doi.org/10.1007/ s40618-016-0438-4

11. Maalouf J, Barron J, Gunn JP, Yuan K, Perrine CG, Cogswell ME. lodized salt sales in the United States. Nutrients. 2015;7(3):1691-5. https://doi.org/10.3390/nu7031691

12. Roulier M, Coppin FE, Bueno M, Nicolas M, Thiry Y, Vedova CD, et al. lodine budget in forest soils: influence of environmental conditions and soil physicochemical properties. Chemosphere. 2019;224:20-8. https://doi. org/10.1016/j.chemosphere.2019.02.060

13. Taylor PN, Albrecht D, Scholz A, Gutierrez-Buey G, Lazarus JH, Dayan CM, et al. Global epidemiology of hyperthyroidism and hypothyroidism. Nat Rev Endocrinol. 2018;14(5):301-16. https://doi.org/10.1038/ nrendo.2018.18

14. Azzakhninia I, Abdelouasb A, Talbi EH. lodine content in groundwater of North Eastern Morocco and its relation with the incidence of goiter. Mater Today. 2019;13(3):1151-60. https://doi.org/10.1016/j.matpr. 2019.04.083

15. Ershow AG, Skeaff SA, Merkel JM, Pehrsson PR. Development of databases on iodine in foods and dietary supplements. Nutrients. 2018;10(1):100. https://doi.org/10.3390/nu10010100

16. Food Standards Australia \& New Zealand. Australian Food, Supplement and Nutrient Database. Canberra: FSANZ; 2013 [cited Apr. 29 2019]. Available from: https://www.foodstandards.gov.au/science/monitoring nutrients/ausnut/ausnutdatafiles/Pages/foodnutrient.aspx 
17. Musaiger AO. Food composition tables for Kingdom of Bahrain. Manama: Arab Center of Nutrition; 2011 [cited June 10 2019]. Available from: http://www.fao.org/fileadmin/templates/food_composition/documents/ pdf/FOODCOMPOSITONTABLESFORBAHRAIN.pdf

18. Technical University of Denmark. Frida database. Denmark: Technical University of Denmark; 2019 [cited May 12 2019]. Available from: https://frida.fooddata.dk/disclaimer

19. Ministerio de Ciencia e Innovación (España). Base de Datos Española de Composión de Alimentos. Madrid: BEDCA database; 2007 [citado 13 abr 2019]. Disponible: https://www.bedca.net/bdpub/index_en.php

20. Agency for Food, Environmental and Occupational Health Safety (France). Ciqual French food composition table. Paris: The Agency; 2019 [cited March 15 2019]. Availabre from: https://ciqual.anses.fr/

21. National Institute for Public Health and the Environment (Netherlands). Nederlands Voedingsstoffenbestand (NEVO). Bilthoven: Institute; 2019 [cited Feb. 15 2019]. Available from: https://nevo-online.rivm.nl

22. European Institute Oncology. Banca Dati di Composizione degli Alimenti per Studi Epidemiologici in Italia. Milan: The Institute; 2015 [cited Apr. 29 2019]. Available from: http://www.bda-ieo.it/wordpress/en/?page_ $\mathrm{id}=21$

23. Ministry of Education, Culture, Sports, Science and Technology (Japan). Standards Tables of Foods Composition in Japan. 7. ed. Tokyo: The Ministry; 2015 [cited Feb. 3 2019]. Available from: https://www. mext.go.jp/en/policy/science_technology/policy/title01/detail01/sdetail01/sdetail01/1385122.htm.

24. Norwegian Food Safety Authority. Norwegian Food Composition Database. Oslo: The Norwegian Directorate of Health and University of Oslo; 2019 [cited Apr. 3 2019]. Available from: www.matvaretabellen.no

25. Plant and Food Research, Ministry of Healthy (New Zealand). New Zealand Food Composition Database: Concise New Zealand Food Composition Tables. Auckland: The New Zealand Institute for Plant and Food Research Limited; 2019 [cited May 10 2019]. Available from: https://www.foodcomposition.co.nz/foodfiles/ concise-tables/

26. Public Health England. Composition of foods integrated dataset (CoFID). London: Public Health England; 2019 [cited Apr. 10 2019]. Available from: https://www.gov.uk/government/publications/composition-offoods-integrated-dataset-cofi

27. Swedish Food Agency. The food database. Uppsala: The Agency; 2019 [cited May 23 2019]. Available from: https://www.livsmedelsverket.se/en/food-and-content/naringsamnen/livsmedelsdatabasen

28. Federal Department of Home Affairs (Switzerland). The Swiss Food Composition Database. Bern: Federal Food Safety and Veterinary Office; 2019 [cited Feb. 27 2019]. Available from: https://www.naehrwertdaten. ch/de/

29. Ministry of Agriculture and Forestry (Turkey). Food Composition Database. Bursa: Central Research Institute for Food and Feed Control; 2019 [cited June 2 2019]. Available from: www.turkomp.gov.tr/?locale=en

30. Instituto Brasileiro de Geografia e Estatística. Pesquisa de Orçamentos Familiares 2008-2009: tabela nutricional dos alimentos consumidos no Brasil. Rio de Janeiro: Instituto; 2011.

31. Paz S, Rubio C, Gutiérrez AJ, Revert C, Hardisson A. lodine: an essential trace element. Med J Clin Trials Case Stud. 2018;2(4):71. https://doi.org/10.23880/mjccs-16000171

32. Bonglaisin JN, Ngondé EMC, Tsafack TJJ, Nlend MN, Mbakop CD, Wirsiy, et al. Monitoring and impact evaluation of iodized salt intervention in Cameroon. Heliyon. 2019;5(5):e01670. https://doi.org/10.1016/j. heliyon.2019.e01670 